Rocznik Gdański, t. LXXX 2020 PL ISSN 0080-3456

https://doi.org/10.26881/rgtn.2020.03

MONIKA TOMKIEWICZ

Instytut Pamięci Narodowej w Warszawie, Biuro Badań Historycznych w Warszawie https://orcid.org/0000-0001-5012-3699

\title{
ZBRODNIA POMORSKA 1939 R. W POWIECIE TCZEWSKIM: SPRAWCY, OFIARY, PAMIĘĆ, ODPOWIEDZIALNOŚĆ
}

Pojęciem „zbrodnia pomorska 1939” określamy akty eksterminacji bezpośredniej dokonane na ludności polskiej od pierwszych dni września 1939 r. do pierwszych miesięcy 1940 r. Zbrodnia ta została dokonana przez oddziały Volksdeutscher Selbstschutz ${ }^{1}$ przy aktywnym wsparciu Wehrmachtu, SS i wszystkich struktur policyjnych, w tym również Einsatzgruppen de Sicherheitspolizei und des Sicherheitsdienst, w skład których wchodziły oddziały operacyjne - Einsatzkommando (EK). Była to akcja zaplanowana i masowa, przeprowadzona na terenie ponad 400 miejscowości w przedwojennym województwie pomorskim, w tym również na terenie powiatu tczewskiego. Proceder ten polegał na ujęciu Polaków i osadzeniu ich w aresztach i punktach zbiorczych, a następnie wytypowaniu spośród tej grupy osób przeznaczonych do rozstrzelania. Ze względu na zacieranie śladów zbrodni oraz częściowe zniszczenie archiwum Volksdeutscher Selbstschutz skalę tych akcji trudno precyzyjnie oszacować liczbowo. Wiadomo jednak, że zbrodnie popełnione na Pomorzu Gdańskim jesienią 1939 r. były w tym czasie największą tego typu operacją w okupowanej Polsce i pierwszą wielką akcją eksterminacyjną wymierzoną w ludność cywilną. Polscy historycy szacują, że w 1939 r. na Pomorzu Gdańskim Niemcy zamordowali od 20000 do 40000 osób². Do tej pory z imienia i nazwiska zidentyfikowano blisko 10000 ofiar. Listy z ustalonymi

1 Volksdeutscher Selbstschutz - Samoobrona Niemców Etnicznych.

2 Według szacunkowych danych Czesław Madajczyk podał minimalną liczbę zamordowanych - 20000 osób, Kazimierz Radziwończyk i Dariusz Matelski - 30 000, a Barbara Bojarska 40 000, Cz. Madajczyk, Polityka narodowościowa władz hitlerowskich na Pomorzu [w:] Najnowsze Dzieje Polski: materiały i studia z okresu II wojny światowej, t. 9, Warszawa 1965, s. 5; K. Radziwończyk, „Akcja Tannenberg” grup operacyjnych Sipo i SD w Polsce jesienia 1939 r., "Przegląd Zachodni” 1966, nr 5, s. 103; B. Bojarska, Eksterminacja inteligencji polskiej na Pomorzu Gdańskim (wrzesień-grudzień 1939), Poznań 1972, s. 51-68, 129-132; D. Matelski, Niemcy w Polsce w XX wieku, Warszawa-Poznań 1999, s. 193. 
nazwiskami straconych stanowią materiał dowodowy śledztw prowadzonych w Oddziałowej Komisji Ścigania Zbrodni przeciwko Narodowi Polskiemu w Gdańsku³. W literaturze naukowej nie funkcjonował do tej pory termin „zbrodnia pomorska 1939 r.". Częściej można było spotkać określenie „krwawa pomorska jesień”, „pogrom”, „nieniemiecki Katyń 1939", jak również Intelligenzaktion i Säuberungsaktion. Dopiero w kilku ostatnich latach w związku z pracami badawczymi prowadzonymi przez historyków zatrudnionych w gdańskim Oddziale Instytutu Pamięci Narodowej termin ten został doprecyzowany $y^{4}$.

Po zakończeniu I wojny światowej, odzyskaniu przez Polskę niepodległości i utworzeniu w sierpniu $1919 \mathrm{r}$. województwa pomorskiego nastąpiły istotne zmiany w strukturze ludnościowej Tczewa i mniejszych miejscowości położonych na terenie powiatu. Po 1920 r. część osób narodowości niemieckiej, która nie chciała pozostać pod rządami polskimi, zdecydowała przenieść się do Rzeszy lub do Wolnego Miasta Gdańska, część się zrepolonizowała. Na teren powiatu przybywała natomiast masowo ludność polska. W 1921 r. po pierwszej dużej fali emigracji i imigracji ludność polska największego miasta w powiecie, Tczewa, wynosiła $60,1 \%$ ogółu mieszkańców, a niemiecka $-25,9 \%$. W powiecie zamieszkiwało wówczas 35700 osób, w tym 6300 Niemców, stanowiących 17,8\% ogółu mieszkańców. W 1931 r. powiat obejmował powierzchnię $716 \mathrm{~km}^{2}$

3 Kilka tysięcy nazwisk osób zamordowanych na terenach byłych województw gdańskiego i bydgoskiego znajduje się w dwóch opracowaniach wewnętrznych wydanych przez Główną Komisję Badania Zbrodni Hitlerowskich w Polsce zatytułowanych: Rejestr miejsc i faktów zbrodni popełnionych przez okupanta hitlerowskiego na Ziemiach Polskich w latach 1939-1945, województwo gdańskie, Warszawa 1987, s. 223, oraz Rejestr miejsc i faktów zbrodni popełnionych przez okupanta hitlerowskiego na Ziemiach Polskich w latach 1939-1945, województwo bydgoskie, Warszawa 1981, s. 144. W wyniku śledztw Oddziałowej Komisji Ścigania Zbrodni przeciwko Narodowi Polskiemu w Gdańsku, prowadzonych od lat sześćdziesiątych do dnia dzisiejszego, ustalono kilkaset nowych nazwisk osób zamordowanych w pierwszych miesiącach II wojny światowej w następujących powiatach położonych na terenie przedwojennego województwa pomorskiego: brodnickim, bydgoskim, chełmińskim, chojnickim, grudziądzkim, inowrocławskim, kartuskim, kościerskim, lipnowskim, lubawskim, morskim, nieszawskim, rypińskim, sępoleńskim, starogardzkim, szubińskim, świeckim, tczewskim, toruńskim, tucholskim, wąbrzeskim, włocławskim, wyrzyskim.

4 Więcej na temat „zbrodni pomorskiej 1939 roku” m.in. w opracowaniach: D. Steyer, Eksterminacja ludności polskiej na Pomorzu Gdańskim w latach 1939-1945, Gdynia 1967; B. Bojarska, Eksterminacja inteligencji polskiej...; T. Jaszowski, E. Pyszczyński, Fordońska dolina śmierci, Bydgoszcz 1975; W. Jastrzębski, J. Sziling, Okupacja hitlerowska na Pomorzu Gdańskim w latach 1939-1945, Gdańsk 1979; S. Grochowina, J. Sziling, Barbarka. Miejsce niemieckich egzekucji Polaków z Torunia i okolic (październik-grudzień 1939), Toruń 2009; A. Gąsiorowski, Zbrodnia w Piaśnicy na tle innych miejsc kaźni na terenie okupowanej Polski [w:] Piaśnica oskarża. Pokłosie konferencji naukowej „Piaśnica 1939-1941” i IV Powiatowo-Gminnego Konkursu Fotograficznego „Nekropolia Piaśnicka”, red. S. Janke, Wejherowo-Bolszewo 2009, s. 7-28; T.S. Ceran, Im Nahmen des Führers. Selbstschutz Westpreussen i zbrodnia w Łopatkach w 1939 roku, Bydgoszcz-Gdańsk 2014; D. Drywa, Säuberungsaktion na Pomorzu Gdańskim w świetle dokumentów KL Stutthof 1939-1942, Sztutowo 2015; Zapomniani kaci Hitlera. Volksdeutscher Selbstschutz w okupowanej Polsce 1939-1940. Wybrane zagadnienia, red. I. Mazanowska, T.S. Ceran, Bydgoszcz-Gdańsk 2016; I. Mazanowska, Karolewo 1939. Zbrodnie w obozie Selbstschutz Westpreussen, Bydgoszcz-Gdańsk 2017; T. Ceran, I. Mazanowska, M. Tomkiewicz, Zbrodnia pomorska 1939, Warszawa 2018. 
zamieszkałą przez 67400 ludności (w tym 4300 Niemców, czyli 6,5\% ogółu mieszkańców). W samym Tczewie mieszkało wówczas 2100 Niemców (9,4\%). W 1939 r. Tczew zamieszkiwało 24800 osób, a powiat tczewski - $66200^{5}$.

W okresie dwudziestolecia międzywojennego napięcia społeczne pomiędzy Polakami i Niemcami zamieszkującymi powiat tczewski uwidaczniały się w manifestacjach, jak również w incydentalnych aktach agresji i morderstwach. W powiecie tczewskim eskalacja konfliktu polsko-niemieckiego nastąpiła na początku 1939 r., kiedy to w czasie zebrań członków Partii Młodoniemieckiej (Jungdeutsche Partei in Polen, JDP) zaczęto sporządzać listy proskrypcyjne Polaków przeznaczonych do „wywózki” i do „likwidacji”'.

2 września 1939 r. powiat tczewski został zajęty przez wojska niemieckie. W tym samym dniu Landratem Tczewa (niem. Dirschau) został Otton Andres ${ }^{7}$, którego 18 września 1939 r. zastąpił Reinhold Isendick ${ }^{8}$. Burmistrzem Tczewa mianowano dr. Gerharda Regiera9. W Pelplinie (niem. Pelplin) burmistrzem został Gerard Räther, a w Gniewie (niem. Mewe) - Horst Wilhelm Walpuski vel Walldorf. Dowódcą SS i Selbstschutzu na miasto Tczew i powiat tczewski został SS-Sturmbanführer Walter Becker ${ }^{10}$, a szefem Gestapo w Tczewie - Georg Wolff ${ }^{11}$.

5 M. Mroczko, Stosunki narodowościowe na Pomorzu w latach 1920-1939, „Zeszyty Naukowe Wydziału Humanistycznego Uniwersytetu Gdańskiego" 1975, nr 4, s. 88; K. Halicki, Samorząd Powiatowy w powiecie tczewskim w latach 1920-1939 r., Tczew 2016, s. 7-55; W. Długokęcki, Historia Tczewa, Tczew 1998, s. 325.

6 W. Długokęcki, Historia Tczewa..., s. 325.

7 Otton Andres, ur. 28 grudnia 1902 r. w Treyenhagen, z zawodu inżynier. Skazany wyrokiem Sądu Okręgowego w Gdańsku 10 lutego 1949 r., sygn. Ksn 224/48, na 15 lat więzienia, Bundesarchiv Ludwigsburg [dalej: BAL], sygn. 3 AR 1254/61, b.p.

8 Reinhold Isendick, ur. 18 listopada 1901 r. w Gdańsku. Przed wojną pracownik Senatu Wolnego Miasta Gdańska. Od 1 listopada 1939 r. starosta Dirschau. Należał do NSDAP (nr 1293 463). Pełnił również funkcję dowódcy SS i Policji w Gdańsku. Pod koniec wojny rozstrzelany w Meklemburgii, BAL, Centralna kartoteka zbrodniarzy narodowosocjalistycznych; Bundesarchiv Berlin [dalej: BAB], SA Findbuch 1882, b.p.

9 Gerhard Regier, ur. 19 grudnia 1907 r. w Czatkowie koło Tczewa. SS-Untersturmführer, Kreisleiter JDP w Tczewie. 9 kwietnia 1945 r. trafił do rosyjskiej niewoli. Uciekł pod koniec 1945 r. i w 1946 r. zamieszkał w Wyk auf Föhr, gdzie zmarł 10 sierpnia 1985 r., BAL, sygn. B 162/6003, protokół przesłuchania świadka Gerharda Regiera, 8 marca 1963 r., s. 188-192; Standesamt Föhr-Amrum I, Akt zgonu Gerharda Regiera, 10 sierpnia 1985 r., s. 1.

10 Walter Becker, ur. 5 maja 1908 r. w Dortmundzie. W SS od 15 lutego 1932 r. (nr 31 834), w NSDAP (nr 1017 614). W 1938 r. pracownik miejskiej kasy oszczędnościowej w Dortmundzie. Od 1939 r. Selbstschutzführer w Tczewie. Od 1 grudnia 1939 r. do 1 maja 1941 r. Führer des SS-Sturmbannes Dirschau. 31 sierpnia 1949 r. wyrokiem Sądu Przysięgłych przy Sądzie Okręgowym w Dortmundzie, sygn. 10 Ks 6/49, skazany na pięć lat więzienia. Zmarł 4 sierpnia 1999 r. w Dortmundzie, BAL, sygn. 3 AR 1461/62, 3 AR-Z 312/59; BAB, PKA 140 2223, RSA 334/1653, SS Listen A 22/1607, SSO/SS-Fuehr SSO 51; Ch.J.A. Weckbecker, Der Volksdeutsche Selbstschutz in Polen 1939/1940, München 1992, s. 62; Standesamt Dortmund, Akt zgonu Waltera Beckera 4 sierpnia 1999 r.

${ }_{11}$ Hans Georg Wolff, ur. 18 grudnia 1910 r. w Gdańsku, SS-Unterscharführer Abschnitt XXVI Gruppe Nord-Ost, Standarte 36, w marcu 1933 r. wstąpił do SS (nr: 99 931) i NSDAP (nr 2842 063), BAB, VBS 1009-ZA II/15042. 
Władze okupacyjne szybko zaczęły tworzyć obozy internowania dla ludności polskiej. Największe miejsca odosobnienia zlokalizowano w więzieniach sądowych w Tczewie i Gniewie, w Szkole Rzemieślniczej w Tczewie, na terenie byłej tczewskiej fabryki „Arkona”, na zamku w Gniewie oraz w Seminarium Duchownym w Pelplinie. Stamtąd więźniów wywożono do miejsc straceń w Lesie Szpęgawskim, do koszar w Tczewie przy ulicy Harcerskiej, a także do obozu dla jeńców cywilnych Stutthof (Zivilgefangenenlager Stutthof) oraz obozów w Potulicach i Prabutach. Kolejne masowe i pojedyncze egzekucje dokonywane były na tzw. Świńskim Rynku (obecnie Plac Niezłomnych) w Tczewie (13 zamordowanych Polaków) i w lasach koło Skórcza (niem. Skurz) ${ }^{12}$.

$\mathrm{W}$ pierwszym okresie aresztowania w Tczewie prowadzone były przede wszystkim w środowisku przedstawicieli lokalnej elity społecznej i intelektualnej polskiej oraz żydowskiej, a także wśród osób, do których miejscowi Niemcy żywili osobiste urazy. Spośród przedstawicieli inteligencji ujęci zostali głównie lekarze, aptekarze, prawnicy, urzędnicy, kupcy i urzędnicy policji państwowej. W obławach udział brali niemieccy policjanci, żandarmi, funkcjonariusze Gestapo i Schutzpolizei, członkowie SA i SS z jednostki SS-Heimwehr-Sturmbann „Götze” oraz V inspektoratu organizacji Volksdeutscher Selbstschutz. Więźniowie początkowo byli umieszczani $\mathrm{w}$ areszcie mieszczącym się w budynku sądu w Tczewie lub w punktach zbiorczych zorganizowanych w szkołach i piwnicach obok gazowni przy ulicy Kołłąaja. Dopiero po wstępnych przesłuchaniach przenoszono ich do obozu dla zakładników utworzonego w byłych koszarach 2. Batalionu Strzelców Wojska Polskiego ${ }^{13}$. Tczewski obóz przejściowy zorganizowano 10 września $1939 \mathrm{r}$. W obozie tym przez cały okres jego funkcjonowania osadzono około 500 Polaków pochodzących z Tczewa i okolic. Po kapitulacji Lądowej Obrony Wybrzeża umieszczono w nim żołnierzy, funkcjonariuszy straży granicznej i polskiej policji. Obóz funkcjonował do końca listopada 1939 r., kiedy to jego budynki ponownie przejęły wojska niemieckie, a znajdująca się jeszcze w obozie grupa więźniów została przeniesiona do obozu zorganizowanego w budynkach Zespołu Szkół Rzemieślniczych w Tczewie. Do 25 października 1939 r. obóz podlegał organom Wehrmachtu, po tym czasie przeszedł pod zarząd policyjny. Komendantem obozu był SS-Scharfführer Erwin Martens ${ }^{14}$. Przy komendancie działała specjalna komisja, w skład której wchodzili członkowie SS i SA, miejscowy szef Gestapo w Tczewie Hans Georg Wolff (od listopada 1939 r. Adolf

12 BAL, sygn. B 162/6641, Tötung von 13 Polen am 24.1.1940 in Dirschau Reichsgau Danzig-Westpreussen durch ein Erschiessungskommando des SS-Sturmbannes Dirschau als Vergeltung für einem angeblichen Sabotageakt, protokół przesłuchania Ottona Andresa, 14 grudnia 1961 r., s. 5-7; Bundesarchiv Bayreuth [dalej: BA Bayreuth], Ost-Dokumentation [dalej: Ost-Dok], 8/256, Fr. Bonus, Landwirt im Kreis Dirschau. Die allgemeine politische Lage im Kreis Dirschau 1920-1945, s. 1-4; W. Długokęcki, Historia Tczewa..., s. 220; M. Wardzyńska, Był rok 1939. Operacja niemieckiej policji bezpieczeństwa w Polsce Inteligenzaktion, Warszawa 2009, s. 109.

13 BAB, R 70/POLEN, Berichtung einer Umwanderzentralstelle in Danzig-Maschinerfabrik „Arcona” Dirschau, s. 89.

14 Erwin Martens, ur. 23 września 1909 r. w Berlinie, BAB, R 9361-V/147550, b.p. 
Liester) ${ }^{15}$ oraz Landrat Tczewa Reinhold Isendick i burmistrz dr Gerhard Regier. Komisja ta była swoistym „sądem policyjnym” lub „sądem Selbstschutz”, który, kierując się ideologią nazistowską, z pełną dowolnością, bez prowadzenia postępowania dowodowego wydawał polecenia mordowania osadzonych osób. Komisja, analizując listy proskrypcyjne, dowolnie decydowała o losie aresztowanego. Mógł on zostać rozstrzelany, skierowany do obozu koncentracyjnego lub zwolniony ${ }^{16}$. Egzekucje poprzez rozstrzelanie na terenie tczewskich koszar prowadzili członkowie załogi obozu i komanda SA z Gdańska, którego dowódcą był Walter Fröse ${ }^{17}$. Rozstrzeliwań dokonywano grupowo lub pojedynczo w różnych miejscach na terenie koszar, zwłaszcza w miejscu dawnej prochowni i na placu ćwiczeń za koszarami ${ }^{18}$.

Szczególnie intensywnie prześladowaną grupą ludności na Pomorzu Gdańskim w 1939 r. byli księża z Diecezji Chełmińsko-Pelplińskiej. Duchowieństwo, obok nauczycieli, zostało uznane za głównych krzewicieli patriotyzmu polskiego i przeznaczone do unicestwienia. Zagłada księży miała swe podłoże również w ideologicznych założeniach partii narodowosocjalistycznej: religię chrześcijańską planowano wyeliminować w III Rzeszy. Choć przebieg i metody eksterminacji księży były na całym obszarze województwa pomorskiego takie same, to jednak straty poniesione przez to środowisko w poszczególnych powiatach znacznie się różniły. Najwięcej księży zginęło w powiatach północnych (głównie w Lesie Piaśnickim, gdzie zamordowano 40 księży z Gdyni i powiatu morskiego), znacznie mniej w południowo-wschodnich (głównie w grudziądzkim, chełmińskim i świeckim). Najkrwawszy przebieg akcje te miały na terenie siedziby kurii biskupiej diecezji chełmińskiej w Pelplinie. Pelplin został zajęty przez oddziały Wehrmachtu 3 września 1939 r. W gmachu Seminarium Duchownego Niemcy utworzyli Internierungslager, podporządkowany miejscowemu oddziałowi SS. Komendantem tego obozu został komisarz policji Hauptmann Helmut Richter, któremu podlegali m.in.: Olga Lutz, Margareta Lutz, SA-mann Hagenveld Gustav, SS-Obersturmführer Heinz Kutze, Otto Seedig ${ }^{19}$ (ówczesny tymczasowy burmistrz Pelplina) i Gerhard Räther (późniejszy burmistrz Pelplina). Polacy osadzeni w Seminarium Duchownym byli często wzywani do gabinetu Helmuta Richtera

15 Adolf Liester, ur. 15 lutego 1892 r., członek NSDAP i Gestapo w Tczewie. W 1945 r. zastrzelony przez partyzantów, BAL, sygn. B 162/4788, B 162/6641, B 162/18535, b.p.

16 D. Steyer, Założenia i realizacja hitlerowskiej polityki eksterminacyjnej na Pomorzu Gdańskim w latach 1939-1945 [w:] Zbrodnie i sprawcy: ludobójstwo hitlerowskie przed sądem ludzkości i historii, red. Cz. Pilichowski, Warszawa 1980, s. 325-336.

17 Walter Fröse, ur. 14 kwietnia 1905 r. w Biesterfelde, 24 listopada 1953 r. uznany za zmarłego.

18 Oddziałowa Komisja Ścigania Zbrodni przeciwko Narodowi Polskiemu w Gdańsku [dalej: OK. Gd.], sygn. S 81/14/Zn, t. 2, śledztwo w sprawie zbrodni nazistowskich, polegających na zabójstwach w okresie od 5 września 1939 r. do 30 listopada 1939 r. w Tczewie w utworzonym na terenie byłych koszar wojskowych tzw. Internierungslager około 120 obywateli polskich przez funkcjonariuszy III Rzeszy Niemieckiej, Postanowienie Sądu Grodzkiego w Tczewie, Zg 122/47, w sprawie o uznanie za zmarłego Edmunda Raduńskiego, 28 sierpnia 1947 r., s. 309.

19 Otto Seedig, ur. 8 września 1889 r. w Tczewie, zm. 21 października 1980 r. w Dörzbach, Standesamt Dörzbach, Akt zgonu Ottona Seediga, nr 13/1980, s. 1. 
i tam przez niego i SA-manna Gustawa Hagenvelda przesłuchiwani oraz bici. Przed każdym wywiezieniem Polaków na stracenie do Lasu Szpęgawskiego zbierała się „komisja” pod przewodnictwem SS-Sturmbanführera Waltera Beckera. W skład „pelplińskiego sądu Selbstschutz” wchodzili: SS-mann Reinhard Strehlke, SS-mann Heinrich Blauschek ${ }^{20}$, żandarm Otto Werner, SS-mann Emil Tgahrt i Amtskommisar Martin Berger. Po podjęciu decyzji Walter Becker w imieniu sądu stawiał krzyżyk przy nazwisku na listach aresztowanych Polaków, co oznaczało karę śmierci. Już na początku września 1939 r. aresztowano profesora Seminarium ks. Maksymiliana Raszeję, któremu zarzucano uczestnictwo w ukrywaniu akt diecezjalnej biblioteki seminaryjnej. W Pelplinie ujęto wówczas także penitencjarza katedralnego księdza Franciszka Baumgarta oraz rektora czasopisma „Pielgrzym” ks. Jerzego Chudzińskiego ${ }^{21}$. Wszystkich trzech wymienionych księży internowano w pojedynczych celach na terenie Seminarium. 20 października 1939 r. aresztowano w Seminarium osiemnastu kanoników. Zatrzymanych pozbawiono dokumentów osobistych i wyprowadzono z budynku w kierunku pobliskiego Lasku Bielawskiego, do majątku ziemskiego Polko, a następnie przewieziono do koszar tczewskich i zamordowano. Ciała wszystkich zamordowanych tam osób były grzebane na miejscu. W wyniku prac ekshumacyjnych przeprowadzonych na terenie koszar w latach 1945, 1947 i 1976 zidentyfikowano zwłoki 79 ofiar. Szczątki ekshumowanych księży 15 listopada 1945 r. złożono we wspólnej mogile na cmentarzu w Pelplinie. Drugą próbę poszukiwań ciał Polaków zamordowanych w latach 1939-1945 podjęto 9 maja 1947 r., zgodnie z kolejnym postanowieniem Sądu Grodzkiego w Tczewie ${ }^{22}$.

Ostatnim etapem kończącym masowe egzekucje mieszkańców Tczewa i powiatu było rozstrzelanie na Świńskim Rynku 24 stycznia 1940 r. 13 mieszkańców Tczewa. Na terenie dawnej fabryki gazomierzy „Arkona” w Tczewie znajdowały się garaże, w których Niemcy umieścili autobusy i samochody ciężarowe. Ze względu na przechowywanie w tym miejscu materiałów łatwopalnych i pojazdów mechanicznych zachowywano szczególne zasady bezpieczeństwa. W nocy 23 stycznia 1940 r. wybuchł

20 Heinrich Blauschek, ur. 1 grudnia 1909 r. w Tczewie, ślusarz samochodowy. Zmarł pomiędzy 1 czerwca 1989 r. około godz. 18.00 a 2 czerwca 1989 r. około godz. 16.30 w Norymberdze, Standesamt Nürnberg, Akt zgonu Heinricha Franza Blauscheka, nr 2774, 5 czerwca 1989, s. 1.

${ }^{21}$ BAL, sygn. B 162/15876, śledztwo w sprawie obwinionego O. Kowalkego i innych o zbrodnie popełnione na terenie Tczewa, Uwagi końcowe do śledztwa, s. 627; BA Bayreuth, Ost-Dok 8, Mark von Nerling, Pastor in Rauden, Kreis Dirschau, Massnahmen gegenüber der polnischen Bevölkerung 1939-1942, s. 2-3.

22 BAL, sygn. B 162/17207-17210, Tötung von Angehörigen des Domkapitels zu Pelplin bei Kulm/Krs. Dirschau am 20.10.1939, decyzja końcowa postępowania Prokuratury w Bremie, sygn. 29 Js 124/65, s. 362-373; OK. Gd., sygn. S 81/14/Zn, t. 2, protokół przesłuchania świadka Anny Buszkiewicz, 11 listopada 1967 r., s. 222-223; Męczeństwo Duchowieństwa Pomorskiego 1939-1945 Straty wojenne diecezji chetmińskiej, Pelplin 1947, s. 9; F. Manthey, „...Qui Nos Praecesserunt Cum Signo Fidei...": rzecz o profesorach Seminarium Duchownego w Pelplinie pomordowanych, poległych i zmarlych w zwiazku z wojna 1939-1945 [w:] Księga Jubileuszowa 350 lat Wyższego Seminarium Duchownego w Pelplinie, Pelplin 2001, s. 319; J. Sziling, Męczeństwo - stużba - walka. Duchowieństwo diecezji chetmińskiej w latach drugiej wojny światowej 1939-1945, Toruń 2019, passim. 
pożar, w wyniku którego zniszczone zostały pojazdy pocztowe. Prawdopodobną przyczyną pożaru było ustawienie koksowników ogrzewających pomieszczenia zbyt blisko samochodów i w rezultacie - zapłon oparów benzyny. Zdarzenie to stało się pretekstem dla Landrata Reinholda Isendicka do oskarżenia o sabotaż Polaków. 24 stycznia 1940 r. w godzinach rannych w Starostwie Powiatowym w Tczewie odbyła się narada wyższych funkcjonariuszy partyjnych Ortsgruppenleiterów NSDAP w Tczewie pod kierownictwem R. Isendicka i jego następcy Herberta Josta. Grupa ta wytypowała nastawionych patriotycznie Polaków, których przewieziono samochodem ciężarowym na Świński Rynek i rozstrzelano.

Polaków aresztowanych przez członków Selbstschutzu, funkcjonariuszy Gestapo, SS, SA i Schutzpolizei na terenie Gniewu oraz okolicznych wsi (m.in.: w Opaleniu, Lipiej Górze, Wielkich i Małych Walichnowach, Kuchni) osadzono w gniewskim zamku i w więzieniu. Obóz przejściowy w Gniewie istniał od grudnia 1939 r. do lutego $1940 \mathrm{r}$. Mieścił się w piwnicach i salach zniszczonego częściowo zamku, na dziedzińcu koszar i w więzieniu. Straż w obozie pełnili członkowie Selbstschutz, a komendantem obozu był funkcjonariusz o nazwisku Sadowski. W miejscu tym przetrzymywano około 2000 Polaków (kobiet, dzieci i mężczyzn) aresztowanych w Gniewie, Tczewie (w fabryce „Arkona”), Pelplinie i Gdańsku. 24 mieszkańców Tczewa Niemcy w listopadzie 1939 r. wywieźli do Lasu Szpęgawskiego i rozstrzelali (wśród nich: Albina Fąsa, ks. Kazimierza Wojtaszewskiego). Przed wywiezieniem wszyscy osadzeni na zamku zostali zebrani w dużej sali, do której przybyli funkcjonariusze Gestapo i z wcześniej przygotowanych list wyczytywali nazwiska Polaków przeznaczonych do wywiezienia. $\mathrm{W}$ obozie co najmniej dwa razy prowadzona była selekcja, w jej wyniku więźniów wywieziono jako zakładników do obozu w Nowym Porcie koło Gdańska oraz w nieznanym kierunku. Podczas likwidacji obozu część więźniów przetransportowano do Generalnego Gubernatorstwa, część do obozu w Potulicach i Prabutach (obóz mieścił się w zakładzie dla umysłowo chorych), a pozostałych zesłano na prace przymusowe do III Rzeszy ${ }^{23}$.

W drugiej połowie 1939 r. na terenie powiatu tczewskiego miały miejsce liczne pojedyncze egzekucje. Jako przykład może posłużyć tu sprawa zamordowania ks. Teodora Borowskiego i dwóch innych Polaków 20 października 1939 r. w Woli koło Pelplina. Ksiądz Teodor Borowski² ${ }^{24}$ był od 1927 r. proboszczem parafii rzym-

${ }^{23}$ OK. Gd., sygn. S 3/67, śledztwo w sprawie wywożenia Polaków z więzienia i zamku w Gniewie na stracenie do Lasów Szpęgawskich, protokół przesłuchania świadka Józefa Bronka z 28 kwietnia 1967 r., s. 37; BAL, sygn. B 162/15876, Ermittlungen gg. O. Kowalke und Anderes des Verdachts der Tötung von 340 polnischen Zivilisten u.a. Geistlichen und Lehrern, in Dirschau und im Kreis Preussisch-Stargard u.a. durch den Volksdeutschen Selbstschutz zwischen September 1939 und Januar 1940, passim; BA Bayreuth, Ost-Dok 8/256, Fr. Bonus, Landwirt im Kreis Dirschau. Die allgemeine politische Lage im Kreis Dirschau 1920-1945, s. 1-4; J. Matynia, Na szlakach walki i męczeństwa województwa gdańskiego 1939-1945, Gdynia 1967, s. 141-142; Z. Biłgorajska, W. Pietruczuk-Kurkiewiczowia, Gdy byliśmy litera P. Wspomnienia wywiezionych na przymusowe roboty do III Rzeszy, Warszawa 1968, s. 133.

24 Ksiądz Teodor Rugertus Michał Borowski, ur. 27 marca 1877 r. w Węsiorach. Kształcił się w Collegium Marianum w Pelplinie. 13 marca 1904 r. otrzymał święcenia kapłańskie w Seminarium 
skokatolickiej w Garcu Wielkim niedaleko Pelplina. 20 października 1939 r. został zatrzymany na terenie swojej parafii przez funkcjonariuszy SA: braci Alberta ${ }^{25}$ i Alfreda Hackerów ${ }^{26}$ oraz Artura Regiera ${ }^{27}$ i Georga Naua ${ }^{28}$. Wywieziono go samochodem ciężarowym w kierunku wsi Rudno. Prawdopodobnie tego samego dnia do Woli przywieziono samochodem ciężarowym księdza katolickiego ubranego w sutannę i mężczyznę ubranego w strój cywilny. Wraz z ks. Borowskim zostali oni poprowadzeni w okolice nasypu kolejki wąskotorowej i rozstrzelani. Zwłoki zakopano na miejscu zbrodni. Przeprowadzone w 1945 r. czynności ekshumacyjne doprowadziły do ujawnienia i zabezpieczenia szczątków zamordowanych. Rozpoznano wówczas ciało ks. Borowskiego. Nie udało się ustalić przyczyny zgonu ze względu na znaczne zmacerowanie zwłok. Na podstawie zeznań świadków ustalono, że drugim zabitym księdzem był prawdopodobnie wikariusz z parafii w Wielkim Garcu, a osobą świecką - lekarz lub nauczyciel pochodzący z Warszawy. 21 października 1945 r. ekshumowane ciała pochowano na pelplińskim $\mathrm{cmentarzu}^{29}$.

Z kolei 7 września 1939 r. zamordowano Polaka Jana Bobka. W godzinach przedpołudniowych został on aresztowany w swoim domu w Nicponi (niem. Liebenthal) przez przybyłych do jego gospodarstwa kilku funkcjonariuszy SA uzbrojonych w karabiny i pistolety. W jego domu została przeprowadzona rewizja, po której Niemcy wyprowadzili żonę Stefanię Bobek i małoletnich synów: 9-letniego Mariana i 10-letniego

Duchownym w Pelplinie. Należał do polskich organizacji społecznych, m.in. do Towarzystwa Naukowego w Toruniu. 29 marca 1927 r. został proboszczem w Wielkim Garcu, OK. Gd., sygn. S 35.2012. Zn, śledztwo w sprawie zamordowania ks. Teodora Borowskiego i dwóch innych Polaków w nieustalonym dniu w październiku 1939 r. w miejscowości Wola koło Pelplina, powiat Tczew, t. 1, Odpis zupełny aktu urodzenia Teodora Borowskiego, s. 29; Archiwum Diecezjalne w Pelplinie, Akta Konserwatora Diecezjalnego, sygn. 2, Alfabetyczny spis księży-ofiar II wojny światowej, b.p.; H. Mross, Słownik biograficzny kapłanów Diecezji Chetmińskiej wyświęconych w latach 1821-1920, Pelplin 1995, s. 23; W. Gruba, Z dziejów parafii Niepokalanego Poczęcia Najświętszej Marii Panny $w$ Wielkim Garcu, Pelplin 2002, s. 157-158.

25 Albert Hacker, ur. 2 kwietnia 1902 r. w Wielkim Garcu. Członek SA, NSDAP i Ortsgruppenleiterem, zaangażowany w akcje wysiedlania Polaków, OK. Gd., sygn. S 35.2012.Zn, t. 1, Odpis zupełny aktu urodzenia Alberta Hackera, s. 22; Archiwum Instytutu Pamięci Narodowej, sygn. GK 164/5724, Kartoteka poszukiwanych przestępców wojennych stworzona przez Sąd Grodzki w Gniewie, b.p.

26 Alfred Hacker, ur. 30 lipca 1892 r. w Wielkim Garcu, OK. Gd., sygn. S 35.2012.Zn, t. 1, Odpis zupełny aktu urodzenia Alfreda Hackera, s. 27.

${ }_{27}$ Artur Regier, ur. 9 listopada 1912 r. w Szadkach. Poległ 27 marca 1944 r. w Rosji, Staatsanwaltschaft Frankfurt am Main, V 203, AR-Z 312/59, s. 57.

28 Jerzy Nau, ur. 15 grudnia 1896 r. w Wielkim Garcu, OK. Gd., sygn. S 35.2012.Zn, t. 1, Odpis zupełny aktu urodzenia Jerzego Hackera, s. 26.

${ }_{29}$ OK. Gd., sygn. S 35.2012.Zn, t. 1, protokół ekshumacji, 19 października 1945 r., s. 3-3v; tamże, t. 1, Protokół oględzin miejsca zamordowania przez hitlerowców trzech Polaków w Pelplinie 8 marca 1968 r., s. 6-10; A. Męclewski, Peplińska jesień, Gdańsk 1971, s. 102; OK. Gd., sygn. S 35.2012Zn, t. 1, Protokół przesłuchania świadka Augustyna Franciszka Deringa 24 maja 1968 r., s. 14-14v; tamże, t. 1, Protokół przesłuchania świadka Jadwigi Brzozowskiej 27 maja 1968 r.; tamże, t. 1, Protokół przesłuchania świadka Marty Gdaniec 27 maja 1968 r., s. 16; tamże, t. 1, Pismo Archiwum Diecezjalnego w Pelplinie z 30 maja 2012 r., s. 69. 
Kazimierza. Jan Bobek pozostał w pokoju sypialnym. Po krótkim czasie czekająca na zewnątrz rodzina usłyszała dwa wystrzały. Dowody zgromadzone w toku śledztwa prowadzonego przez stronę polską zostały w całości przekazane niemieckim organom ścigania - Zentrale Stelle der Landesjustizverwaltungen in Ludwigsburg celem kontynuowania dochodzenia. Postępowanie karne prowadzone na terenie Niemiec na mocy zarządzenia prokuratury w Hamburgu z 1 lutego 1980 r., sygn. 2100 UJs 2/78 C, zostało umorzone z powodu braku dostatecznych dowodów co do jego sprawców ${ }^{30}$.

Po wojnie sprawy zbrodni popełnionych na terenie powiatu tczewskiego zostały objęte postępowaniami dochodzeniowymi w Polsce i w Niemczech. W 1967 r. Okręgowa Komisja Badania Zbrodni Hitlerowskich w Gdańsku wszczęła kompleksowe śledztwo o sygn. S 3/67 w sprawie zbrodni popełnionych na terenie powiatu tczewskiego w latach 1939-1945. Śledztwo to zostało przez stronę polską zawieszone w 1975 r. z powodu niemożności przesłuchania świadków i osób podejrzanych mieszkających za żelazną kurtyną. W latach 2012-2014 prokurator Oddziałowej Komisji Ścigania Zbrodni przeciwko Narodowi Polskiemu w Gdańsku podjął śledztwo i przeprowadził postępowanie dowodowe $\mathrm{w}$ dochodzeniach:

1. Sygn. S 81.2014.Zn - w sprawie zbrodni nazistowskich polegających na zabójstwach około 120 obywateli polskich przez funkcjonariuszy III Rzeszy Niemieckiej w okresie od 5 września 1939 r. do 30 listopada 1939 r. w utworzonym na terenie byłych koszar w Tczewie tzw. Internierungslager;

2. Sygn. S 35.2012.Zn - w sprawie zamordowania ks. Teodora Borowskiego i dwóch innych Polaków w nieustalonym dniu w październiku 1939 r. w Woli koło Pelplina, powiat Tczew;

3. Sygn. S 37.2012.Zn - w sprawie zamordowania 24 stycznia 1940 r. 13 Polaków na tzw. Świńskim Rynku w Tczewie.

Zaraz po wojnie prokuratury niemieckie działały głównie na podstawie doniesień o przestępstwach popełnionych na terenie ich właściwości miejscowej. Tym sposobem wszczynały postępowania śledcze o przestępstwa wojenne. Dzięki temu strona niemiecka wszczęła postępowania karne, w których na ławie oskarżonych zasiadło kilku sprawców zbrodni popełnionych na terenie powiatu tczewskiego: Walter Becker, Oskar Kowalke ${ }^{31}$, Wilhelm Fast, Erwin Martens, Reinhold Isendick, dr Gerhard Regier, Gustav Hogenfeld ${ }^{32}$, Konrad Radziejewski, Heinrich Blauschek, Adolf Liester,

30 OK. Gd., sygn. S 25.2011.Zn, t. 1, Śledztwo w sprawie zamordowania Jana Bobka w Nicponi, powiat Tczew, 7 września 1939 r.; akt zgonu USC w Gniewie, Nr 75/1945/1, z 29 września 1945 r., s. 17; tamże, t. 1, Protokół przesłuchania świadka Mariana Bobka 2 października 1967 r., s. 11-11v; tamże, t. 1, Protokół przesłuchania świadka Kazimierza Bobka 2 października 1967 r., s. 12-12v; BAL, 21 UJs $2 / 78$ C, b.p.

${ }^{31}$ Oskar Kowalke, ur. 25 marca 1901 r. w Gdańsku, pracownik administracji. Zmarł 6 sierpnia 1982 r. w Wilhelmshaven, Stadtarchiv Wilhelms Haven, Akt zgonu Oskara Kowalke nr 766, 10 sierpnia 1982 r., s. 1.

32 Gustav Hogenfeld, ur. 19 października 1905 r. w Schöneberg, powiat Groses Werder, z zawodu dezynfektor. Zmarł 5 lutego 1972 r., Stadtarchiv Viersen, Akt zgonu Gustava Hogenfelda, nr 158, 7 lutego 1972 r., s. 1. 
Erwin Waltersdorf, Paul Lerchenfeld ${ }^{33}$, Eryk Ludwik Kuhlmann, Edmund Jakob Karlikowski, Jerzy Karlikowski, Alfons Majtkowski vel Mainrad, Wilhelm Kawlowski, Walter Schumacher ${ }^{34}$, Robert Schulz, Herber Schulz, Albert Saenger i Curt Seedig. Prokuratura przy Sądzie Krajowym w Norymberdze (Staatsanwaltschaft bei dem Landgericht Nürnberg-Fürth) prowadziła postępowanie o sygn. 341 Js 33786/80 przeciwko Oskarowi Kowalkemu, Heinrichowi Blauschekowi, Wilhelmowi Kawlowskiemu i innym. Pomimo prowadzonych poszukiwań nie udało się ustalić miejsca pobytu podejrzanych - Karlikowskiego i Kowalkego. Podejrzani Blauschek, bracia Schulzowie, Willi Kawlowski i Walter Schumacher zaprzeczyli, że brali udział w egzekucjach Polaków na terenie koszar w Tczewie. Sprawa została umorzona 20 lipca 1982 r. z braku dostatecznych dowodów sprawstwa określonych osób w morderstwach. Z kolei prokuratura w Stuttgarcie prowadziła dochodzenie o sygn. 17 Js 306/62 przeciwko Curtowi Seedigowi, Amstkomisarzowi NSDAP w Pelplinie, podejrzanemu o udział w zabójstwie 16 księży katolickich i czterech innych Polaków 20 października 1939 r. w Pelplinie. Postanowieniem Sądu Krajowego w Heilbronn (sygn. III ARS 131/63) z 6 maja 1963 r. postępowanie zostało umorzone $\mathrm{z}$ braku dowodów winy oskarżonego. $\mathrm{W}$ tej samej sprawie śledztwo prowadziła także prokuratura w Bremie (sygn. 29 Js 124/65). Zakończyło się ono dyspozycją z 28 maja 1968 r. o umorzeniu. Prokuratura w Lüneburgu prowadziła postępowanie o sygn. 2a Js 41/56 w sprawie przeciwko Joachimowi von Paleskemu. Dyspozycją z 2 lipca 1968 r. i ponowną dyspozycją z 24 maja 1971 r. zostało ono umorzone ${ }^{35}$. Dochodzenie prowadzone przez prokuraturę przy Sądzie Krajowym we Frankfurcie nad Menem o sygn. 4 Js 88/72 zakończyło się orzeczeniem z 29 stycznia 1974 r., z którego wynika, że postępowanie przygotowawcze prowadzone przeciwko obywatelom niemieckim Albertowi Hackerowi i Georgowi Nauowi, podejrzanym o dokonanie zabójstwa trzech Polaków w Woli, zostało umorzone z powodu niemożności potwierdzenia, że podejrzani byli wśród sprawców, jak również z powodu

33 Paul Lerchenfeld, ur. 21 września 1901 r. w Tczewie.

34 Walter Schumacher, ur. 1 listopada 1916 r. w Tiegenhof, do SS wstąpił 19 lutego 1937 r., w SA od 9 listopada 1934 r. (nr: 3467 775). Pracował jako pomoc fryzjerska, BAB, RS/Rasse, F 51150, Walter Schumacher, s. 2; BAL, sygn. B 162/15876, Protokół przesłuchania świadka Waltera Schumachera 11 lipca 1978 r., s. 1110-1114.

35 BAL, sygn. 162/4777, Bd. 1, Erschießung von Angehörigen des Domkapitels zu Pelplin im Krs. Dirschau am 20.10.1939; tamże, sygn. B 162/15872-15877, Ermittlungen gg. O. Kowalke des Verdachts der Tötung von 230 polnischen Zivilisten In Dirschau Und im Kreis Preußische Stargard durch Selbstschutz zwischen September 1939 und Januar 1940; tamże, sygn. B 162/6641, Tötung von 13 Polen am 24.1.1940 in Dirschau durch ein Erschiessungskommando des SS-Sturmbannes Dirschau Preußisch Stargard als Vergeltung für einen angeblichen Sabotageakt; tamże, sygn. B 162/27147-27148, Ermittlungen gg. K. Gabriel und H. Stummeier Landesarbeitsamt Danzig, wg Beteiligung an der Tötung von Polen im Herbst 1939 sowie des Hausmeisters des Arbeitsamtes Danzig im Sommer 1944; tamże, sygn. B 162/5133, Tötung von 13 Polen AM 21.1.1940 in Dirschau durch ein Erschiessungskommando des SS-Sturmbannes Dirschau - Preussisch Stargard; Die Behörde des Bundesbeauftragten für die Stasi-Unterlagen Berlin, sygn. MfS HA IX/11, AK 3331/80, Verbrechen gegen die Menschlichkeit während des faschistischen Überfalls auf Polen im September 1939 in dem Ort Pelplin, 20 grudnia 1979, s. 5-28. 
niewykrycia sprawców. W ocenie niemieckiego prokuratora zebrany materiał dowodowy, a przede wszystkim zeznania polskich świadków nie stanowiły dostatecznych przesłanek wskazujących na sprawstwo podejrzanych. Sami podejrzani Hacker i Nau zaprzeczyli w toku postępowania uczestnictwu w zdarzeniu ${ }^{36}$.

Po wojnie wiele miejsc egzekucji zostało upamiętnionych. W 1962 r. na zachodniej ścianie gniewskiego zamku umieszczono pamiątkową tablicę z wykazem nazwisk 50 osób zamordowanych i napisem: „1939 rok - wrzesień 1962 r. Cześć i Chwała Mieszkańcom Ziemi Gniewskiej pomordowanym przez hitlerowców w latach 1939-1945. Społeczeństwo Ziemi Gniewskiej”. W 1967 r. na Placu Niezłomnych w Tczewie, na dobudowanym murze znajdującym się w odległości $12 \mathrm{~m}$ od tego, pod którym rozstrzelano 13 Polaków w styczniu 1940 r., umieszczono tablicę pamiątkową z nazwiskami osób zamordowanych. 12 marca 1980 r. z okazji 35. rocznicy wyzwolenia Tczewa przy ulicy Wojska Polskiego, przed gmachem Jednostki Wojskowej 3730, odsłonięto obelisk-głaz pamiątkowy poświęcony mieszkańcom Tczewa pomordowanym w 1939 r. w obozie przejściowym w Tczewie. 20 czerwca 2011 r. w Woli, w miejscu zamordowania trzech osób, odsłonięto pomnik-krzyż ${ }^{37} .17$ września 2003 r. biskup pelpliński Jan Bernard Szlaga rozpoczął proces beatyfikacyjny 122 księży - ofiar hitleryzmu. Wśród nich znalazł się pelpliński duchowny ks. dr Józef Roskwitalski ${ }^{38}$ aresztowany 20 października 1939 r. w grupie kanoników i przewieziony do tczewskich koszar. 24 maja 2011 r. podczas uroczystej mszy św. w bazylice katedralnej w Pelplinie dokonano zamknięcia etapu krajowego procesu beatyfikacyjnego części duchownych - męczenników II wojny światowej ${ }^{39}$.

Skala zbrodni popełnionych na Pomorzu Gdańskim jesienią 1939 r. była największa w tym czasie w okupowanej Polsce i jest uznawana za pierwszą tak wielką akcję eksterminacyjną wymierzoną w ludność cywilną. Na podstawie ankiet sądów grodzkich z 1945 r. szacowano, że na terenie powiatu tczewskiego jesienią 1939 r. zamordowano 27 osób,

36 Staatsanwaltschaft bei dem Landgericht Frankfurt am Main, 4 Js 88/72, Ermittlungsverfahren 4 Js 88/72 gegen die deutschen Staatsangehörigen Albert Hacker, Georg Nau, b.p.

37 B. Solecki, W Woli upamiętniono męczeństwo księży, „Informator Pelpliński” 2011, nr 7 (240), s. 13.

38 Ks. dr Józef Roskwitalski, ur. w 1893 r., zamordowany 20 października 1939 r. Rektor i profesor Seminarium Duchownego w Pelplinie, kanonik Kapituły Katedralnej Chełmińskiej. Aresztowany 20 października 1939 r. i zamordowany w koszarach tczewskich, J. Sziling, Męczeństwo - stużba - walka..., s. 186.

39 OK. Gd., sygn. S 81/14/Zn, t. 9, Informacje o ewidencji miejsc zbrodni hitlerowskich na terenie miasta Tczewa sporządzony przez Urząd Miasta Tczewa 26 czerwca 2015 r., s. 1725-1729; OK. Gd., sygn. S 37.2012.Zn, t. 1, Protokół oględzin miejsca stracenia 13 Polaków na Placu Niezłomnych w Tczewie 15 stycznia 1968 r., s. 42; OK. Gd., sygn. S 3/67, Śledztwo w sprawie zamku i więzienia w Gniewie, Dokumentacja techniczna - protokół oględzin celi i pomieszczeń na zamku w Gniewie 5 grudnia 1968 r., s. 244-248; Drugi proces beatyfikacyjny męczenników z okresu II wojny światowej, www.diecezja-pelplin.pl/diecezja/procesy-beatyfikacyjne/1259-ii-proces-beatyfikacyjny-meczennikow-z-okresu-ii-wojny-swiatowej [dostęp: 14.01.2021]; Męczennice II Wojny Światowej, www.sluzebniczkinmp.pl/duchowosc-i-dziedzictwo-swietosci-7391/meczennice-ii-wojny-swiatowej-7425\#1 [dostęp: 14.01.2021]. 
a ankieta przeprowadzona w 1969 r. przez Główną Komisję Badania Zbrodni Hitlerowskich w Polsce wskazywała 371 ofiar $^{40}$. Do tej pory dobrze udokumentowana była tylko liczba straconych księży (bez uwzględnienia członków zgromadzeń zakonnych) diecezji chełmińskiej. Kuria biskupia w Pelplinie wydała bowiem w 1947 r. listę strat, z której wynika, że jesienią 1939 r. zginęło 218 księży, tj. dwie trzecie wszystkich duchownych uśmierconych podczas okupacji na terenie Okręgu Rzeszy Gdańsk - Prusy Zachodnie. Badania nad doprecyzowaniem liczby zamordowanych na terenie całego powiatu tczewskiego trwają nadal. Obecnie historycy z Oddziału Gdańskiego IPN (Tomasz Ceran, Izabella Mazanowska i Monika Tomkiewicz) pracują nad publikacją Zbrodnia pomorska 1939. Dokumentacja terroru niemieckiego. Monika Tomkiewicz opracowuje część dotyczącą zbrodni popełnionej w powiecie tczewskim. Prace badawcze i edycja źródłowa dokumentów są już w zasadzie zakończone. Pozostaje ostatni etap badań, ustalenie przybliżonej, najbardziej wiarygodnej liczby ofiar tej zbrodni.

Pamięć o ofiarach „zbrodni pomorskiej 1939 r.” jest kultywowana w wymiarze lokalnym na terenie każdego jednego z 23 przedwojennych powiatów byłego województwa pomorskiego. Najwyższy czas, aby podjąć próby przybliżenia wiedzy o niej Polakom, a nawet podjąć działania w celu jej umiędzynarodowienia. Warto też pomyśleć o zespoleniu lokalnych środowisk zajmujących się upamiętnianiem ofiar zbrodni popełnionych w okresie II wojny światowej na Pomorzu. Nie możemy również zapominać, iż na terenie przedwojennego województwa pomorskiego, $w$ tym również powiatu tczewskiego, w pierwszym okresie II wojny światowej dokonywane były akty eksterminacji pośredniej, przejawiające się w kierowaniu zatrzymanych do obozów koncentracyjnych (w tym głównie obozu Stutthof, KL Sachsenhausen-Oranienburg, Dachau i Gusen) i licznych lokalnych więzień, gdzie osoby te były torturowane i również mordowane. Także zorganizowane akcje masowych wysiedleń pociągały za sobą ofiary, zwłaszcza wśród osób starszych i małych dzieci, które źle znosiły warunki transportów i życia w miejscu wysiedlenia. W powiecie tczewskim około 1800 polskich rodzin wywieziono na przełomie 1939 i 1940 r. do Generalnego Gubernatorstwa ${ }^{41}$.

Bibliografia

Źródła

Archiwum Instytutu Pamięci Narodowej w Gdańsku.

Archiwum Instytutu Pamięci Narodowej w Warszawie.

Archiwum Muzeum Stutthof w Sztutowie.

Archiwum Państwowe w Gdańsku.

Archiwum Oddziałowej Komisji Ścigania Zbrodni przeciwko Narodowi Polskiemu w Gdańsku.

Bundesarchiv Bayreuth.

Bundesarchiv Berlin.

Bundesarchiv Ludwigsburg.

40 W. Jastrzębski, J. Sziling, Okupacja hitlerowska na Pomorzu Gdańskim..., 95-96.

${ }^{41}$ W. Długokęcki, Historia Tczewa..., s. 328. 
Die Behörde des Bundesbeauftragten für die Stasi-Unterlagen Berlin (BStU Berlin).

Institut für Zeitgeschichte München.

Standesamt Dortmund.

Standesamt Dörzbach.

Standesamt Föhr-Amrum I.

Standesamt Nürnberg.

Stadtarchiv Viersen.

Staatsanwaltschaft bei dem Landgericht Frankfurt am Main.

\section{Literatura}

Biłgorajska Zofia, Pietruczuk-Kurkiewiczowia Władysława, Gdy byliśmy litera P. Wspomnienia wywiezionych na przymusowe roboty do III Rzeszy, Ludowa Spółdzielnia Wydawnicza, Warszawa 1968.

Bojarska Barbara, Eksterminacja inteligencji polskiej na Pomorzu Gdańskim (wrzesień-grudzień 1939), Instytut Zachodni, Poznań 1972.

Ceran Tomasz Syriusz, Im Nahmen des Führers. Selbstschutz Westpreussen i zbrodnia w Łopatkach w 1939 roku, Instytut Pamięci Narodowej - Komisja Ścigania Zbrodni przeciwko Narodowi Polskiemu, Oddział w Gdańsku, Bydgoszcz-Gdańsk 2014.

Ceran Tomasz Syriusz, Mazanowska Izabela, Tomkiewicz Monika, Zbrodnia pomorska 1939, Instytut Pamięci Narodowej, Warszawa 2018.

Długokęcki Wiesław, Historia Tczewa, Kociewski Kantor Edytorski, Tczew 1998.

Drugi proces beatyfikacyjny męczenników z okresu II wojny światowej, www.diecezja-pelplin.pl/diecezja/procesy-beatyfikacyjne/1259-ii-proces-beatyfikacyjny-meczennikow-z-okresu-ii-wojny-swiatowej [dostęp: 14.01.2021].

Drywa Danuta, Säuberungsaktion na Pomorzu Gdańskim w świetle dokumentów KL Stutthof 1939-1942, Muzeum Stutthof, Sztutowo 2015.

Gąsiorowski Andrzej, Zbrodnia w Piaśnicy na tle innych miejsc kaźni na terenie okupowanej Polski [w:] Piaśnica oskarża. Pokłosie konferencji naukowej „Piaśnica 1939-1941” i IV Powiatowo-Gminnego Konkursu Fotograficznego „Nekropolia Piaśnicka”, red. Stanisław Janke, Urząd Gminy Wejherowo, Biblioteka Publiczna Gminy Wejherowo im. Aleksandra Labudy, WejherowoBolszewo 2009, s. 7-28.

Grochowina Sylwia, Sziling Jan, Barbarka. Miejsce niemieckich egzekucji Polaków z Torunia i okolic (październik-grudzień 1939), Fundacja Generał Elżbiety Zawackiej, Archiwum i Muzeum Pomorskie Armii Krajowej oraz Wojskowej Służby Polek, Toruń 2009.

Gruba Wojciech, Z dziejów parafii Niepokalanego Poczęcia Najświętszej Marii Panny w Wielkim Garcu, Bernardinum, Pelplin 2002.

Halicki Krzysztof, Samorzą Powiatowy w powiecie tczewskim w latach 1920-1939 r., Bernardinum, Tczew 2016.

Jastrzębski Włodimierz, Sziling Jan, Okupacja hitlerowska na Pomorzu Gdańskim w latach 1939-1945, Wydawnictwo Morskie, Gdańsk 1979.

Jaszowski Tadeusz, Pyszczyński Edmund, Fordońska dolina śmierci, Bydgoszcz 1975. Madajczyk Czesław, Polityka narodowościowa władz hitlerowskich na Pomorzu [w:] Najnowsze Dzieje Polski: materiały i studia z okresu II wojny światowej, t. 9, Państwowe Wydawnictwo Naukowe, Warszawa 1965, s. 5-33.

Manthey Franciszek, „... Qui Nos Praecesserunt Cum Signo Fidei...”: rzecz o profesorach Seminarium Duchownego $w$ Pelplinie pomordowanych, poległych i zmarlych $w$ zwiazku z wojna 1939-1945 [w:] Księga Jubileuszowa 350 lat Wyższego Seminarium Duchownego w Pelplinie, Bernardinum, Pelplin 2001, s. 319-335.

Matelski Dariusz, Niemcy w Polsce w XX wieku, Wydawnictwo Naukowe PWN, Warszawa-Poznań 1999.

Matynia Jerzy, Na szlakach walki i męczeństwa województwa gdańskiego 1939-1945, Wydawnictwo Morskie, Gdynia 1967. 
Mazanowska Izabela, Karolewo 1939. Zbrodnie w obozie Selbstschutz Westpreussen, Instytut Pamięci Narodowej - Komisja Ścigania Zbrodni Przeciwko Narodowi Polskiemu, Oddział w Gdańsku, Bydgoszcz-Gdańsk 2017.

Męclewski Alojzy, Pelplińska jesień, Wydawnictwo Morskie, Gdańsk 1971.

Męczennice II Wojny Światowej, www.sluzebniczkinmp.pl/duchowosc-i-dziedzictwo-swietosci-7391/ meczennice-ii-wojny-swiatowej-7425\#1 [dostęp: 14.01.2021].

Męczeństwo Duchowieństwa Pomorskiego 1939-1945 Straty wojenne diecezji chełmińskiej, Pelplin 1947.

Mroczko Marian, Stosunki narodowościowe na Pomorzu w latach 1920-1939, „Zeszyty Naukowe Wydziału Humanistycznego Uniwersytetu Gdańskiego" 1975, nr 4, s. 85-101.

Mross Henryk, Słownik biograficzny kapłanów Diecezji Chetmińskiej wyświęconych w latach 1821-1920, Bernardinum, Pelplin 1995

Radziwończyk Kazimierz, „Akcja Tannenberg” grup operacyjnych Sipo i SD w Polsce jesienia 1939 r., „Przegląd Zachodni” 1966, nr 5, s. 102-105.

Rejestr miejsc ifaktów zbrodni popelnionych przez okupanta hitlerowskiego na Ziemiach Polskich w latach 1939-1945, województwo gdańskie, Główna Komisja Badania Zbrodni Hitlerowskich w Polsce, Warszawa 1987.

Rejestr miejsc i faktów zbrodni popetnionych przez okupanta hitlerowskiego na Ziemiach Polskich w latach 1939-1945, województwo bydgoskie, Ministerstwo Sprawiedliwości. Główna Komisja Badania Zbrodni Hitlerowskich w Polsce, Warszawa 1981.

Solecki Bogdan, W Woli upamiętniono męczeństwo księży, „Informator Pelpliński” 2011, nr 7 (240), s. 13.

Steyer Donald, Eksterminacja ludności polskiej na Pomorzu Gdańskim w latach 1939-1945, Wydawnictwo Morskie, Gdynia 1967.

Steyer Donald, Założenia i realizacja hitlerowskiej polityki eksterminacyjnej na Pomorzu Gdańskim w latach 1939-1945 [w:] Zbrodnie i sprawcy: ludobójstwo hitlerowskie przed sądem ludzkości i historii, red. Czesław Pilichowski, Państwowe Wydawnictwo Naukowe, Warszawa 1980, s. 325-336.

Sziling Jan, Męczeństwo - stużba - walka. Duchowieństwo diecezji chełmińskiej w latach drugiej wojny światowej 1939-1945, TNT, Toruń 2019.

Wardzyńska Maria, Był rok 1939 Operacja niemieckiej policji bezpieczeństwa w Polsce Inteligenzaktion, Instytut Pamięci Narodowej - Komisja Ścigania Zbrodni przeciwko Narodowi Polskiemu, Warszawa 2009.

Weckbecker Christian, Jansen Arno, Der Volksdeutsche Selbstschutz in Polen 1939/1940, R. Oldenbourg Verlag, München 1992.

Zapomniani kaci Hitlera. Volksdeutscher Selbstschutz w okupowanej Polsce 1939-1940. Wybrane zagadnienia, red. Izabela Mazanowska, Tomasz Syriusz Ceran, Instytut Pamięci Narodowej - Komisja Ścigania Zbrodni przeciwko Narodowi Polskiemu, Bydgoszcz-Gdańsk 2016.

\section{Streszczenie}

Zbrodnia pomorska 1939 r. była przede wszystkim eksterminacją dziesiątek tysięcy przedstawicieli polskiej inteligencji, rozstrzelanej w ramach „Inteligenzaktion”, ale także rolników, robotników i rzemieślników, zamordowanych przez niemieckich sąsiadów. Po zajęciu powiatu tczewskiego przez wojska niemieckie od 2 września 1939 r. władze okupacyjne zaczęły tworzyć obozy internowania i punkty zbiorcze w więzieniach dla ludności polskiej. $\mathrm{Na}$ terenie powiatu tczewskiego miejsca takie znajdowały się w więzieniach sądowych w Tczewie i Gniewie, Szkole Rzemieślniczej w Tczewie, na terenie Fabryki „Arkona” w Tczewie, na terenie zamku w Gniewie oraz w Seminarium Duchownym w Pelplinie. Stamtąd więźniowie wywożeni byli do miejsc straceń w Lesie Szpęgawskim i w koszarach w Tczewie. Egzekucje poprzez rozstrzelanie na terenie koszar prowadzili członkowie załogi obozu „Internierungslager” i komanda SA w Gdańsku. Rozstrzeliwań dokonywano głównie na terenie 
dawnej prochowni i na placu ćwiczeń za koszarami. Ciała zamordowanych były grzebane na terenie koszar. Zginęło tam wówczas około 120 osób. W grupie tej byli pracownicy polskiej administracji, przedstawiciele inteligencji, adwokacji, nauczyciele i duchowni (w tym 20 księży kapituły pelplińskiej). W wyniku prac ekshumacyjnych przeprowadzonych w 1945, 1947 i 1976 r. zidentyfikowano zwłoki 79 osób. Obóz tczewski funkcjonował do stycznia 1940 r. i w jego murach osadzono około 500 więźniów.

Słowa kluczowe: zbrodnia pomorska 1939 r., punkty zbiorcze dla Polaków w Tczewie, obozy dla jeńców cywilnych, Volksdeutscher Selbstschutz, więzienie w koszarach w Tczewie, kapituła katedralna w Pelplinie

The Pomeranian crime of 1939 in the Tczew district: perpetrators, victims, rememberance, responsibility

Summary

The Pomeranian crime of 1939 principally involved the extermination of tens of thousands of the Polish intelligentsia Polish civilians, executed under the Intelligenzaktion, but also farmers, workers, and craftsmen murdered by German neighbours. Following the take-over of the Tczew district by the German troops, the occupation authorities commenced opening internment camps and organizing assembly points in prisons for the Polish population. In the Tczew district area such points were situated at the court holding cells at Tczew and Gniew, at Tczew Technical School, at the premises of the "Arkona" factory in Tczew, at the Gniew castle as well as the Pelplin Seminary. From there the inmates were transported to the mass execution sites in the Szpęgawskie Forests and to the army barracks in Tczew. Executions by firing squad at the army barracks in Tczew were conducted by members of the "Internierungslager" as well as the SA Command at Gdańsk. The firing squad executions were conducted predominantly on the premises of the former gunpowder depot and on the parade grounds behind the army barracks. The bodies of the executed inmates were buried on the premises of the army barracks. Nearly 120 people died there at that time. The group included Polish civil servants, intellectuals, lawyers, teachers and priests (including 20 priests from the Pelplin Chapter). Following exhumations carried out after the war in 1945 and 1976, the remains of 79 persons were identified. The Tczew camp was in operation until January 1940 and held approximately 500 inmates within its walls.

Keywords: The Pomeranian crime of 1939, collection and Transit camps for Poles in Tczew, camps for civilian, prisoners: Volksdeutscher Selbstschutz, prison in the barracks in Tczew, cathedral chapter in Pelplin 